\title{
EFFECT OF CURING PERIOD, REST PERIOD AND MIX PROPORTION ON GEOPOLYMER CONCRETE
}

\author{
Shrikant M. Harle \\ Assistant Professor, Department of Civil Engineering, \\ Prof Ram Meghe College of Engineering and Management, Badnera, Maharashtra, India \\ shrikantharle@gmail.com
}

\begin{abstract}
The geopolymer concrete is the new binding agent in place of cement and it utilizes the alternative materials like fly ash. This type of concrete is eco-friendly material as it does not emit the $\mathrm{CO} 2$ gases in the environment up to hazardous level. The polymeric reaction between fly ash and alkaline chemical activator solution like sodium silicate and sodium hydroxide to form gel is occurred in geopolymer concrete. The experimental work on the different proportion ratios of material used in the concrete mix and effect of rest period on the compressive strength of concrete cubes are tested. Sodium silicate is used based on its normality of $1 \mathrm{~N}$ and $2 \mathrm{~N}$, sodium hydroxide is used of 12 molar. The rest period is considered for the test was $1,2,3,4,5$ and 7 days. Thermal curing in hot oven under the controlled temperature of $60^{\circ} \mathrm{C}, 65^{\circ} \mathrm{C}, 95^{\circ} \mathrm{C}, 125^{\circ} \mathrm{C}$ and $135^{\circ} \mathrm{C}$ for 24 and 48 hours is considered. It was observed that for curing temperature of $90^{\circ} \mathrm{C}$ to $100^{\circ} \mathrm{C}$ shall give the good compressive strength.
\end{abstract}

Key Words : geopolymer concrete, rest period, thermal curing, fly ash and chemical activator

\section{Introduction}

The development of the fly ash based geopolymer concrete is the need of an hour to obtain greener concrete in order to reduce the $\mathrm{CO} 2$ emission from the production of cement. To replace th use of ordinary Portland cement in concrete and also to reduce the $\mathrm{CO} 2$ emission this green concrete offers significant opportunity [1]. The availability of fly ash worldwide creates opportunity to utilize this byproduct of burning coal, as a substitute for ordinary Portland cement to manufacture the concrete. Fly ash reacts with the calcium hydroxide during the hydration process of OPC to form the calcium silicate hydrate gel [2 \& 3].

In 1978 J. Davidovits developed an alternative binder to $\mathrm{OPC}$ as a result of the polymerization process of silicon \& aluminum from the source material which reacts with alkaline solution \& this process is known as Geopolymer. There are two main constituents of geopolymer, firstly the source material and the alkaline liquids. The source material can be the byproduct like fly ash, silica fume, slag, rice husk ash, etc. The alkaline liquids are from soluble alkali metals that are mostly sodium or potassium based materials. The commonly used alkaline liquid which is used in geopolymerization consists of combination of sodium hydroxide $(\mathrm{NaOH}) /$ potassium hydroxide $(\mathrm{KOH})$ and sodium silicate / potassium silicate [4\&5].

In the geopolymer concrete the strength is gained due to polymeric reaction which takes place between the silica and alumina in fly ash with high alkali activated solution.
The geopolymers are the members of the family of the inorganic polymers. The geopolymerization process involves the chemical reaction of alumina-silicate oxides with alkali polysilicates yielding the polymeric bonds [6].

The study was carried out that the amount of the $\mathrm{CO} 2$ released during the manufacture of OPC due to calcinations of limestone and combustion of fossil fuel [7]. It was found that the compressive strength of hot cured specimen is more than that of ambient cured spwcimen. The 7 days compressive strength of hot cured specimen found around 3 times more than that of ambient cured specimen [8].

It was observed that the geopolymer concrete based on pozzolana is a new material that does not need the presence of Portland cement as a binder. The researcher observed that the workability of fresh geopolymer concrete is the effect of extra water on slump test [9].

The researcher suggested that when the ratio of liquid to fly ash increased then the flow and setting time also increased [10]. To improve the workability the small amount of chemical admixture such as water reducing agent or retarder are commonly used in the production of concrete [11].

The study was carried out on the flow of fly ash based geopolymer concrete which increases with increase in water to geopolymer binder ratio by maintaining other parameters such as aggregates and fly ash [12, $13 \& 14]$. It also showed that the geopolymer concrete is more viscous with decrease in water to geopolymer binder 
ratios by reducing the quantity of water in the mixes $[15$, $16 \& 17]$.

The study was carried out on the geopolymer concrete results from the reaction of a source material which is rich in silica and alumina with alkaline liquid [18 \&19]. The recent application of geopolymer concrete was included in the study [20]. The geopolymer concrete has excellent properties and it is mainly suited to manufacture the precast concrete products which are needed in rehabilitation and retrofitting of structure [21 \& 22].

\section{Experimental Programme}

\subsection{Materials}

\subsubsection{Sand:}

The locally available sand is used for the presented experimental investigation for the geopolymer concrete. The sand is sieved from IS sieve size $2.18 \mathrm{~mm}, 1.10 \mathrm{~mm}$, $600 \mu, 300 \mu$ and $150 \mu$ and taken in the proper proportion for the mixing of geopolymer concrete. After sieving, it was washed by potable water and the silt, clay particles, other contaminants are removed by washing the sand. The specific gravity of the sand is determined as 2.78 by Pycnometer method.

\subsubsection{Aggregates:}

The locally available aggregates of $20 \mathrm{~mm}$ size saturated surface dry conditions are used in the preparation of geopolymer concrete. As per the IS 2366 (part IV)-1963 is used to determine the engineering properties of aggregates. The table no. 1 shows the engineering properties of aggregates.

Table 1

Physical properties of aggregates

\begin{tabular}{|c|l|l|}
\hline Sr. No. & Test parameter & Test values \\
\hline 1 & Specific gravity & 2.78 \\
\hline 2 & Crushing test & $11.175 \%$ \\
\hline 3 & Impact test & $5.11 \%$ \\
\hline 4 & Abrasion test & $6.44 \%$ \\
\hline
\end{tabular}

\subsubsection{Alkaline activator solution}

The alkaline activator is a combination of sodium silicate solution and sodium hydroxide solution that can be used as the alkaline liquid. Sodium silicate is the common name for a compound of sodium meta silicate, Na2Sio3.

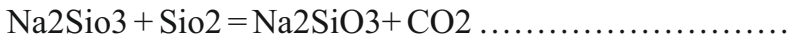
(Eq. 1)

The sodium hydroxide with $97-98 \%$ purity, in flake or pellet form is commercially available. The solids must be dissolved in water to make a solution with the required concentration. The concentration of sodium hydroxide solution can vary in the range from 8 molar to 16 molar. The mass of $\mathrm{NaOH}$ solids in a solution varies depending upon the concentration of the solution.

\subsubsection{Sodium hydroxide}

Sodium hydroxide $(\mathrm{NaOH})$ also known as caustic metallic base. It is used in many industries mostly as a strong chemical base in the cleaner.

Sodium silicate and the sodium hydroxide and sodium hydroxide solution were mixed together one day prior to the use in preparing the geopolymer concrete. The ratio of the sodium silicate solution to the sodium hydroxide solution was fixed as $1.0 \%$. the sodium silicate was used in the powder terms

\subsubsection{Mix Proportion}

Three series of test sample of geopolymer concrete is prepared with different mix proportion. $12 \mathrm{~N}$ of sodium hydroxide and sodium silicate solution prepared with $2 \mathrm{~N}$. activator to fly ash is considered as 0.35 while the sodium silicate to sodium hydroxide ratio is taken as 1 for all the mixes. The following table shows the mix proportion of geopolymer concrete.

Table 2

Mix proportion of geopolymer concrete

\begin{tabular}{|c|c|c|c|c|c|c|}
\hline $\begin{array}{c}\mathrm{S} \\
\mathrm{N}\end{array}$ & $\begin{array}{c}\text { Mix } \\
\text { proporti } \\
\text { on }\end{array}$ & $\begin{array}{l}\text { Fly } \\
\text { ash } \\
(\mathrm{Kg})\end{array}$ & $\begin{array}{c}\text { Fine } \\
\text { aggregates } \\
(\mathrm{kg})\end{array}$ & $\begin{array}{c}\text { Coarse } \\
\text { aggregate } \\
(\mathrm{kg})\end{array}$ & $\begin{array}{c}\mathrm{NaO} \\
\mathrm{H} \\
\text { flakes } \\
\text { form } \\
(\mathrm{kg})\end{array}$ & $\begin{array}{c}\mathrm{Na}_{2} \mathrm{Si} \\
\mathrm{O}_{3} \\
\text { powder } \\
\text { form } \\
(\mathrm{kg})\end{array}$ \\
\hline 1 & $1: 1.1: 3.4$ & 408 & 448.80 & 1387.2 & 480 & 284 \\
\hline 2 & $1: 1.2: 3.3$ & 408 & 489.60 & 1540.4 & 480 & 284 \\
\hline 3 & $1: 1.3: 3$ & 408 & 530.40 & 1224 & 480 & 284 \\
\hline 4 & $1: 1.4: 3.1$ & 408 & 571.20 & 1264.8 & 480 & 284 \\
\hline$J$ & $1: 1.5: 3.2$ & 408 & 612.0 & 1305.6 & 480 & 284 \\
\hline 6 & $1: 1.5: 3$ & 408 & 612.0 & 1224 & 480 & 142 \\
\hline
\end{tabular}

From the above table it can be observed that the mix proportion of geopolymer concrete is varies for the samples of cubes. Also the following table shows the molarity of $\mathrm{NaOH} \&$ normality of $\mathrm{Na} 2 \mathrm{SiO} 3$ for the various samples of cubes.

Table 3

Composition of Geopolymer concrete

\begin{tabular}{|c|c|c|c|c|}
\hline $\begin{array}{c}\text { Sample } \\
\text { No. }\end{array}$ & $\begin{array}{c}\text { Molarity } \\
\text { of NaOH }\end{array}$ & $\begin{array}{c}\text { Normality } \\
\text { of } \mathrm{Na}_{2} \mathrm{SiO}_{3}\end{array}$ & $\begin{array}{c}\text { Activator/ } \\
\text { fly ash ratio }\end{array}$ & $\begin{array}{c}\text { Mix } \\
\text { proportion }\end{array}$ \\
\hline Sample 1 & $12 \mathrm{M}$ & $2 \mathrm{~N}$ & 0.36 & $1: 1.1: 3.4$ \\
\hline Sample 2 & $12 \mathrm{M}$ & $2 \mathrm{~N}$ & 0.30 & $1: 1.2: 3.3$ \\
\hline Sample 3 & $12 \mathrm{M}$ & $2 \mathrm{~N}$ & 0.35 & $1: 1.3: 3.0$ \\
\hline Sample 4 & $12 \mathrm{M}$ & $2 \mathrm{~N}$ & 0.35 & $1: 1.4: 3.1$ \\
\hline Sample 5 & $12 \mathrm{M}$ & $2 \mathrm{~N}$ & 0.35 & $1: 1.5: 3.2$ \\
\hline Sample 6 & $12 \mathrm{M}$ & $1 \mathrm{~N}$ & 0.35 & $1: 1.5: 3.0$ \\
\hline
\end{tabular}


From the above table the activator to fly ash ratio is varied for different samples. The sample estimation for $1 \mathrm{cum}$ concrete mix is shown in the following table

Table 4

Estimation for 1cum geopolymer concrete mix

\begin{tabular}{|c|l|l|}
\hline Sr. No. & Name of materials & Quantity \\
\hline 1 & Fly ash & $5370 \mathrm{gms}$ \\
\hline 2 & Sand & $5907 \mathrm{gms}$ \\
\hline 3 & Aggregate & $1926 \mathrm{gms}$ \\
\hline 4 & Activator solution & $1920 \mathrm{ml}$ \\
\hline
\end{tabular}

\subsubsection{Mixing \& curing procedure:}

Firstly prepare the dry mix of geopolymer concrete by using fly ash, sand and aggregates with the help of trowel for five minutes. Then add the activator solution and mixed it thoroughly on firm dry surface properly for 10 to 15 minutes as shown in the following fig. no.1.

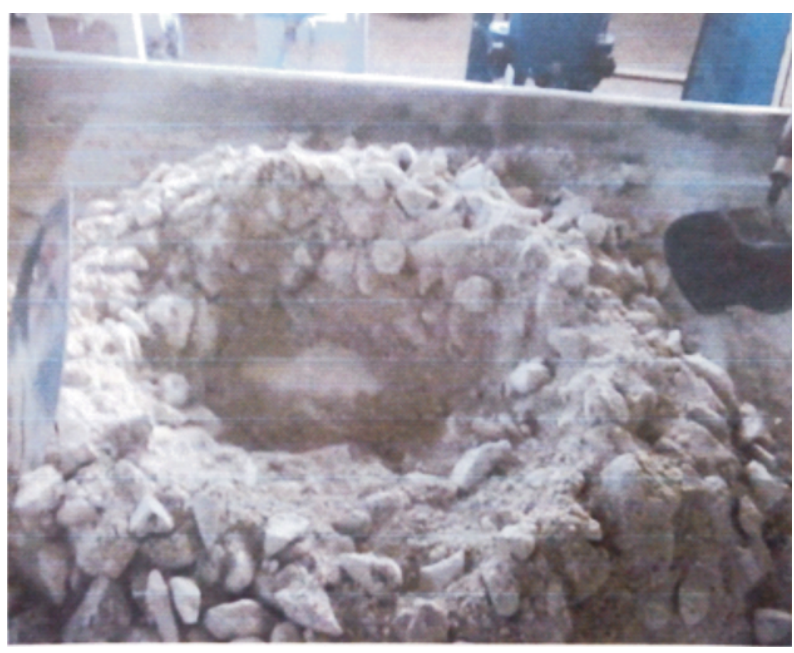

Fig. 1: Dry mix of geopolymer concrete

Use the moulds of size of $150 \mathrm{mmX} 150 \mathrm{mmX} 1500$ for making concrete cubes. The geopolymer concrete is filled in three equal layers and hand compaction is done by using $16 \mathrm{~mm}$ diameter bar of $600 \mathrm{~mm}$ length. Each layer is compacted 25 times equally distributed on its cross sectional area.

\subsubsection{Workability of fresh mix of geopolymer concrete}

The geopolymer concrete is workable with hand mixing and it is depends on time taken for mixing and the proportion if ingredients used for mixing. In the present work it is observed that the time taken for mixing more than 10 to 15 minutes. Following figure shows the workability test by slump cone.

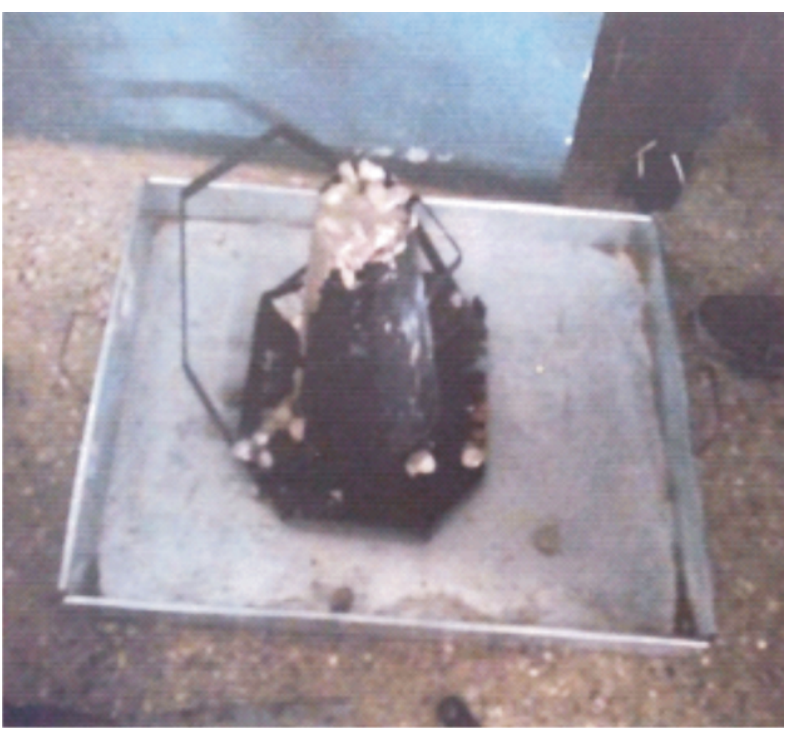

Fig. 2 : slump cone test of geopolymer concrete

\subsection{Curing of geopolymer concrete:}

After casting the moulds, it should keep for 1, 2, 3, 4, 5 and 7 days of rest period for all the mixesat elevated temperatures. After completion of rest period then remold the concrete specimen from the mould. The following table shows the curing details of geopolymer concrete.

Table 4

Curing details of geopolymer concrete

\begin{tabular}{|c|c|c|c|c|}
\hline $\begin{array}{c}\text { Sr. } \\
\text { No. }\end{array}$ & $\begin{array}{c}\text { Mix } \\
\text { proportion }\end{array}$ & $\begin{array}{c}\text { Curing } \\
\text { temperature } \\
\left({ }^{\circ} \mathrm{C}\right)\end{array}$ & $\begin{array}{c}\text { Curing } \\
\text { time } \\
\text { (hours) }\end{array}$ & $\begin{array}{c}\text { Rest } \\
\text { period } \\
(\text { days })\end{array}$ \\
\hline 1 & $1: 1.1: 3.4$ & 60 & 24 & 4 \\
\hline 2 & $1: 1.2: 3.3$ & 65 & 24 & 2 \\
\hline 3 & $1: 1.3: 3.0$ & 75 & 48 & 3 \\
\hline 4 & $1: 1.4: 3.1$ & 95 & 48 & 5 \\
\hline 5 & $1: 1.5: 3.2$ & 125 & 48 & 7 \\
\hline 6 & $1: 1.5: 3.0$ & 135 & 48 & 1 \\
\hline
\end{tabular}

From the above table it shows that there are different mix proportions and different rest period before curing. All the geopolymer concrete cubes were allowed to cool at room temperature for five days after thermal curing. The following figure shows the thermal curing of geopolymer concrete. 


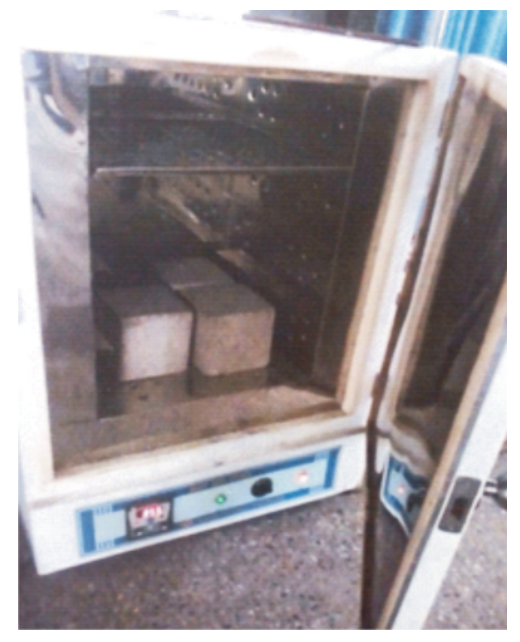

Fig. 3 : Thermal curing of geopolymer concrete cubes

The term 'rest period' was coined to indicate the time taken from the completion of casting of test specimens to the start of curing at an elevated temperature. The following figure shows the concrete cubes after thermal curing and before the compressive test.

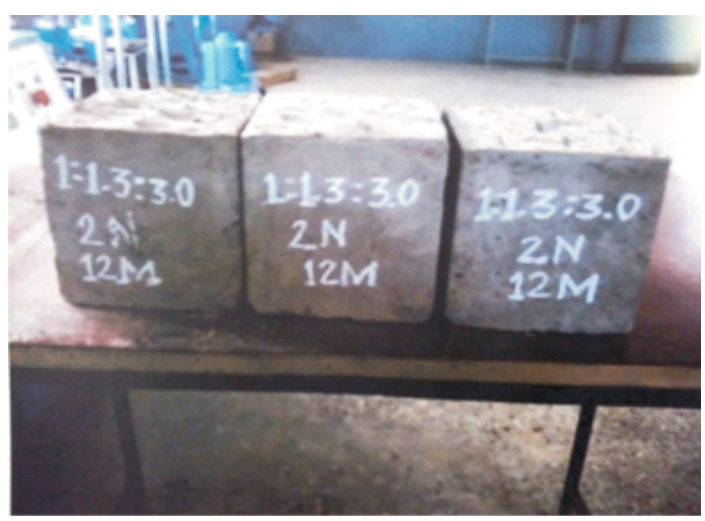

Fig. 4 : concrete cubes before thermal curing

The concrete cubes are tested for compressive strength and the failure of the concrete cubes is observed and it is shown in the following figure.

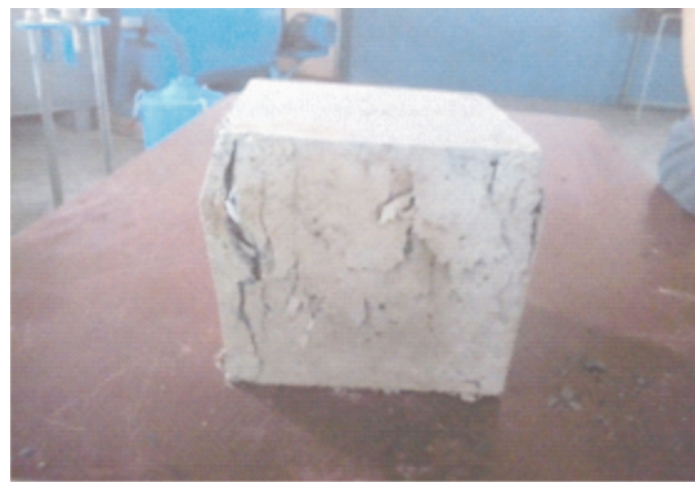

Fig. 5 : failure surface of the geopolymer concrete cube

\section{Results}

The geopolymer concrete cube with varying mix proportions, temperature and curing period are tested for compressive strength. The following table shows the compressive strength of concrete cubes.

Table 5

Compressive strength of geopolymer concrete

\begin{tabular}{|c|c|c|c|c|c|}
\hline $\begin{array}{l}\text { Sr. } \\
\text { No. }\end{array}$ & $\begin{array}{l}\text { Mix } \\
\text { propor } \\
\text { tion }\end{array}$ & $\begin{array}{l}\text { Tempe- } \\
\text { rature } \\
\text { of curing }\end{array}$ & $\begin{array}{l}\text { Period } \\
\text { of } \\
\text { curing }\end{array}$ & $\begin{array}{l}\text { Compre- } \\
\text { ssive } \\
\text { strength } \\
\left(\mathrm{N} / \mathrm{mm}^{2}\right)\end{array}$ & $\begin{array}{l}\text { Average } \\
\text { compress } \\
\text { ive } \\
\text { strength } \\
\left(\mathrm{N} / \mathrm{mm}^{2}\right)\end{array}$ \\
\hline \multirow[t]{3}{*}{1} & \multirow[t]{3}{*}{ 1:1.1:3.4 } & \multirow[t]{3}{*}{60} & \multirow[t]{3}{*}{24} & 3.73 & \multirow[t]{3}{*}{4.35} \\
\hline & & & & 5.02 & \\
\hline & & & & 4.31 & \\
\hline \multirow[t]{3}{*}{2} & \multirow[t]{3}{*}{$1: 1.2: 3.3$} & \multirow[t]{3}{*}{65} & \multirow[t]{3}{*}{24} & 7.5 & \multirow[t]{3}{*}{7} \\
\hline & & & & 7.66 & \\
\hline & & & & 5.97 & \\
\hline \multirow[t]{3}{*}{3} & \multirow[t]{3}{*}{ 1:1.3:3.0 } & \multirow[t]{3}{*}{75} & \multirow[t]{3}{*}{48} & 4.8 & \multirow[t]{3}{*}{4.71} \\
\hline & & & & 4.53 & \\
\hline & & & & 4.8 & \\
\hline \multirow[t]{3}{*}{4} & \multirow[t]{3}{*}{$1: 1.4: 3.1$} & \multirow[t]{3}{*}{95} & \multirow[t]{3}{*}{48} & 14.66 & \multirow[t]{3}{*}{15} \\
\hline & & & & 17.82 & \\
\hline & & & & 12.27 & \\
\hline \multirow[t]{3}{*}{5} & \multirow[t]{3}{*}{ 1:1.5:3.2 } & \multirow[t]{3}{*}{125} & \multirow[t]{3}{*}{48} & 6.4 & \multirow[t]{3}{*}{6.07} \\
\hline & & & & 6.04 & \\
\hline & & & & 5.77 & \\
\hline \multirow[t]{3}{*}{6} & \multirow[t]{3}{*}{$1: 1.5: 3.0$} & \multirow[t]{3}{*}{135} & \multirow[t]{3}{*}{48} & 5.02 & \multirow[t]{3}{*}{4.89} \\
\hline & & & & 4.76 & \\
\hline & & & & 4.9 & \\
\hline
\end{tabular}

\section{Compressive strength}

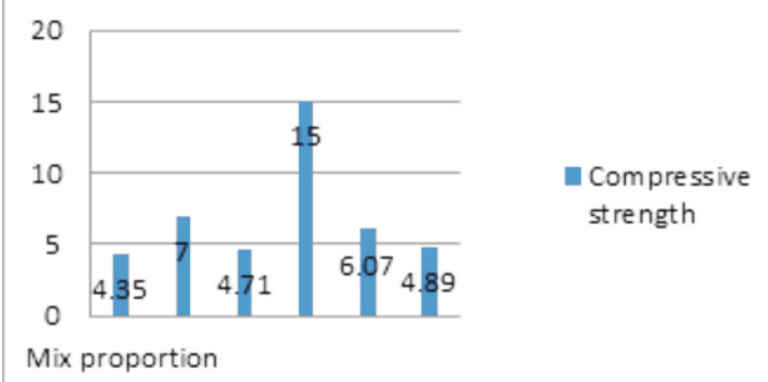

Fig. 6 : Compressive strength of geopolymer concrete 
From the above table and graph it is observed that the compressive strength of rest period at 5th day is maximum as compared to $3 \mathrm{rd}$ and 7 th days. Also the compressive strength for mix proportion of $1: 1.4: 3.0$ is maximum. The curing temperature of $95^{\circ} \mathrm{C}$ for 48 hours gives the maximum compressive strength.

\section{Conclusion}

The geopolymer concrete is manufactured from predominantly silica and alumina containing source material. From the present work it can be concluded that the geopolymer concrete specimen manufactured with higher alkali cement performed better than those manufactured with lower alkali content. At the moderate rest period the compressive strength increases then it is gradually decreases. The curing temperature is in the range between $90^{\circ} \mathrm{C}$ to $100^{\circ} \mathrm{C}$, compressive strength found maximum. For the higher strength results then the mix proportion factor should take into account. If the activator solution content is increased in the mix then the workability of geopolymer concrete is more. Also it is found that the sodium silicate which was used in the powder form, found to be less effective than the liquid form as used by other researchers.

\section{References}

[1] D. Hardjito, "Introducing fly ash based geopolymer concrete manufacturing and engineering properties", Curtin University of technology, 30th conference on our world in concrete and structures, Singapore, 2324 August 2005.

[2] Malhotra V. M., "High performance high volume fly ash concrete", ACI concrete international, 24 (7), pp $1-5,2002$.

[3] Malhotra V. M., "introduction: sustainable development and concrete technology", ACI concrete international, 24 (7), 22, 2002.

[4] Malhotra V. M. "Role of supplementary cementing materials and superplasticizers in reducing greenhouse gas emissions", ICFRC, Chennai, India, Allied publishers pvt 1td, 2004.

[5] Gourley J. T. and Johnson G. B., "Developments in geopolymer precast concrete", proceedings of the international workshop on geopolymer and geopolymer concrete, Perth, Australia, 2005.

[6] Davidovits J., "Chemistry of geopolymeric systems, terminology of chemical technology", 99th international conference Prague, January 2005.

[7] Cheng T. W. and J. P. Chiu, "Fire resistant geopolymer produced by granulated blast furnace slag", Mineral engineering, 16(3), pp 205-210, 2003.

[8] Nirgi Dave, "Experimental evaluation of low calcium fly ash based geopolymer concrete", International journal of engineering science and technology, 2010.
[9] Nguyen Van Chan, "Recent research on geopolymer concrete", 3rd ACF international conference, Vietnam, 2008.

[10] M.I. Abdul Aleem and P. D. Arumairaj, "Optimum mix for geopolymer concrete", Indian journal of science and technology, 2012.

[11] Pratap Kishanrao, "Design of geopolymer concrete", International journal of innovative research in science, engineering and technology, vol.2, May 2013.

[12] Pattanapong Topark Ngarm, "Effect of admixtures on high calcium geopolymer concrete cured at room temperature",4th KKU international engineering, Khon Kaen University and Khon Kaen, Thailand, 2012.

[13] Ganapati Naidu and P. Prasad, "Study on strength properties of geopolymer concrete", international journal of engineering research and development, vol2, July 2012.

[14] V. Sreevidya and R. Anuradha, "Acid resistance of fly ash based geopolymer mortar under ambient and heat curing", International journal of engineering science and technology, vol. 4, February 2012.

[15] D. Hardjito, "Introducing fly ash based geopolymer concrete manufacturing and engineering properties", 30 th conference on our world in concrete and structure, Singapore August 2005.

[16] Ammar Motorwala, "Alkali activated fly ash based geopolymer concrete", international journal of emerging technology and advanced engineering, vol.3, issue 1, January 2013.

[17] N.A. Lloyd and B. V. Rangan, "Geopolymer concrete with fly ash", 2nd international conference on sustainable construction materials and technologies, Ancona, Italy, 2010.

[18] Dody M. J. Sumajouw, "Development of fly ash based geopolymer concrete", Acis materials journal, American concrete institute, 2004.

[19] V. bhikshma, "An experimental investigation on properties of geopolymer concrete", Asian journal of civil engineering, vol.13, issue 6, 2012.

[20] B. Vijaya Rangan, "Geopolymer concrete for environmental protection", The Indian concrete journal, vol. 88, issue 4, pp 41-48, 2014.

[21] S Ganesh Kumar, Dr M IAbdulAleem and S Dinesh, "Applications of geopolymer concrete", International research journal of engineering and technology, vol. 2, issue 9, 2015.

[22] Sonal P. Thakkar, Darpan J. Bhorwani and Rajesh Ambaliya, "Geopolymer concrete using different source material", International journal of emerging technology and advanced engineering, vol 4, special issue 4, 2014. 